\title{
SISAL FIBER - DIVERSIFIED APPROACH FOR INCOME GENERATION
}

\author{
PADMA ALAPATI ${ }^{1} \&$ KHATEEJA SULTHANA SHAIK ${ }^{2}$ \\ ${ }^{I}$ Principal Scientist, Aicrp - H. Sc. (Clothing \& Textiles), Pg \& Rc, Pjtsau, Rajendranagar, \\ Hyderabad, Telangana, India \\ ${ }^{2}$ Senior Research Fellow, Aicrp - H. Sc. (Clothing \& Textiles), Pg \& Rc, Pjtsau, Rajendranagar, \\ Hyderabad, Telangana, India
}

\begin{abstract}
Today main concern is on health, sustainable waste management and environmental awareness are reflecting the ad hoc interest in plant fibers. This can result in environmentally friendly fibers, fabrics and their products, which can lead to trendy organic fashions

The hunt is on for ecologically friendly fabrics. The movement toward trendy organic fashions and alternative fashion has led to the revival and revision of traditional fibers with natural and organic approaches. We have different regenerated natural fibers like pineapple, jute, coir, bamboo, etc., having high strength are known to have effectively diversified utilization.

The concern of the consumers for variety in textiles is driving the textile industry for designing and producing new textiles from time to time. The efforts were taken to develop eco-friendly and biodegradable fibers to control nonpolluting environment. The renewed sisal fiber is produced because of its high potential applications. Enzymes are playing a major role in the finishing of textiles in an eco-friendly way, protects the environment on one side and on the other side provides a gentle finish. Sisal fiber is one among the natural fibers, which have huge application in many fields. In the present paper, sisal fiber's utilization in diversified methods is shown, which include agro- mats, union fabric, composites, handmade papers, and handicrafts. Similarly, any bast fiber can be used to develop such type of environmentally friendly products.
\end{abstract}

KEYWORDS: Waste Management, Fibers, Textiles \& Handicrafts

Received: Aug 08, 2018; Accepted: Aug 29, 2018; Published: Nov 01, 2018; Paper Id.: IJESRDEC20184

\section{INTRODUCTION}

Sisal is not a seasonal crop. It is one of the most extensively cultivated hard fibers in the world and it accounts for half the total production of textile fibers (Lock 1962 and Wilson 1971). Sisal fiber is obtained from leaves of the plant Agave Sisalana, which was originated from Mexico and is now mainly cultivated in East Africa, Brazil, Haiti, India and Indonesia (Nilsson, 1975; Mattoso et al. 1997). It is grouped under the broad heading of the "Hard fibers" among which sisal is placed second to Manila in durability and strength (Weindling, 1947), due to which, it can easily grow in all states of India covering subhumid to arid and semiarid regions, covering almost all soil types, which leads to its least costing for survival, regeneration, and maintenance on sustainable basis.

Presently sisal fibers are collected and utilized for conventional purposes like ropes, anchors, cordage, etc. To cope with the burning issues like under-utilized wastelands, unemployment in rural and semi-urban areas, environmental degradation, etc., innovative approaches must be carried out in terms of strengthening non-farm 
sectors by fabricating under-utilized minor fibers.

In turn, diversified end products can meet the demands of national and international textile industries, which can be obtained at different steps in the processing of product (from to fiber to end product). The present research paper is based on 'Usage of Sisal Fiber for Diversified Application'.

\section{METHODOLOGY}

\section{Fiber Extraction}

Fiber was extracted from Agave webert leaves using Rasipdar Machine, a mechanical method. The fibers were washed and beaten to remove the pith and later treated with 5 percent Sodium Hydroxide for delignification. These fibers are given enzymatic treatment using cellulosic enzymes in MLR of 1:30 and pH 5 for 30 min (M. Siresha, 2013).

\section{Sisal Diversified Usage}

Using the extracted sisal fiber, union fabric and different diversified products like nonwoven, agro mats, handmade paper, handicrafts, paper carry bags and composites were developed.

\section{Union Fabric Development}

Weave sisal fiber with cotton to produce union fabrics. A weaver twisted sisal fibers are fused form a continuous length fiber with the required twist, which was therefore given at Southern groups' handloom unit, Malikipuram (Rajahmundry) for the weaving of Union fabric according to the required woven structure M. Siresha, 2013.

\section{Nonwoven}

Non-woven mats were prepared by random laid web bonding method (Corbman, 1983).

\section{Agro Mats}

Depend on the diameter of the plant pots, Sisal non-woven was cut in different sizes.

\section{Handmade Paper}

Sisal handmade paper was prepared by sisal fiber pulp in molds using vat machine.

\section{Handmade Paper's Carry Bags}

It was prepared by folding a handmade paper in a box shape and sealing on one side and fixing eyelet through riveting to insert cord for holding the bag.

\section{Handicrafts}

Braiding/plaiting/macramé techniques were used to make different handicrafts with sisal fibers. A fiber was dyed to get different color variations

\section{Composites}

Resin transfer molding technique was used for making composites with Sisal nonwovens and handmade papers. 


\section{RESULTS AND DISCUSSIONS}

\section{Sisal Fiber Properties}

The main composition of sisal fiber consists of 66-72 per cent cellulose, 12 per cent hemicelluloses, 10-14 per cent lignin, pectin 1 per cent and wax 0.3 per cent. And the superior engineering properties are diameter 50-200 mm, microfibril angle 10-220, an ultimate tensile strength of 468-640 MPa; modulus of 9.40-15.80 GPa and elongation of 3-7 per cent makes it as an excellent material for manufacturing high strength textile and reinforcement in composites for various applications.

\section{Union Fabric Development}

Yarn count, fabric count, and fabric weight were increased, which may be due to the enzyme treatment made the fiber soft, pliable and lightened the fiber as well as improving compactness in weaving. Decreased stiffness was observed for enzyme treated fibers, which results in the good handle properties by showing increased crease recovery angle, as well improved its aesthetic feel.

With respect to mechanical properties, with an increase in enzyme concentration, there was a decrease in tensile and tear strength was observed, which is due to the changes in the molecular structure of the fiber. Regenerated and improved sisal fibers at optimized levels can give good handle properties, enhancing their apparel suitability.

\section{Nonwoven}

Nonwoven made in different thicknesses can be utilized for varied end products, depend on the type on its usage and flexibility. Example, little thicker nonwoven can be used for agro mats and a thinner one for composite making.

\section{Agro Mats}

Agro mats were used in the nursery pot for conserving water consumption. Through research on water conservation, over a period of observation, it was found that there was 40-50 percentage of water can be conserved with $2 \mathrm{~mm}$ thickness sisal agro mat, Padma and Khateeja, 2016. Being a natural source, sisal can be easily biodegradable. It can last for one crop period if used as mulch in horticulture fields.

\section{Handmade Paper, Carry Bags and Handicrafts}

All these are entrepreneurial activities like making of handmade papers; carry bags, files \& folders; and handicrafts can be beneficiary to women groups for sustainable income generation. With the fiber, many handicrafts like wall hangings and utility products like pouches, handbags, purses, etc can be prepared. If perceived as group activity like SHGs, NGOs, these items can immensely support them financially. Srinivasa kumar et. al., 2013 have indicated the scope of development to rural, semi-urban and urban through its allied activities and engineered applications respectively. According to Filho, et. al., 1990, reinforced composite materials like door panels, corrugated roofing sheets, etc can be made with sisal fiber, which can further attract entrepreneur and stakeholders.

All India Coordinated Research Project on Home Science, Clothing and Textiles component, Hyderabad have motivated and trained a group of SHG members to do these types of crafts, who has participated in exhibition cum sales and have received appreciations for their innovative approach for income generation. 


\section{Composites}

An acceptable level of strength in composites was observed. These composites can be effectively utilized in the different field activities by farm workers. An increase in compression, which might be due to the reinforcement and compatibility of the resin with reinforcement, was also observed. Less flexural strength is due to the random orientation of fibers which is far removed from the uniform distribution.

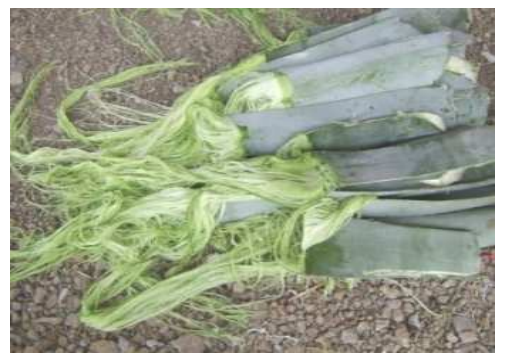

(a) Fiber from Sisal Leaves Figure 1: Extracted Sisal Fiber and Dying of Fiber

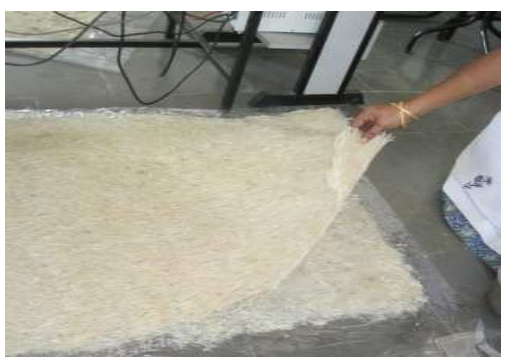

(a) Sisal Non Woven

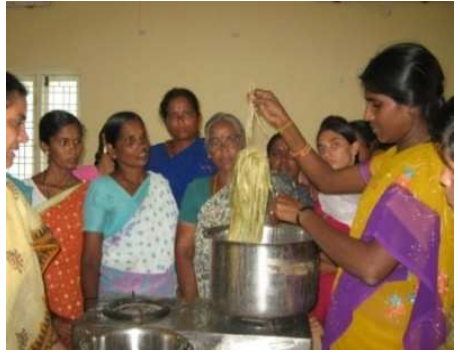

(b) Dyeing of Sisal Fiber

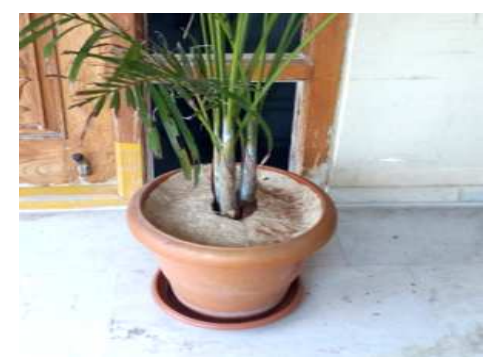

(b) Sisal Agro Mat

Figure 2: Sisal Agro Mat

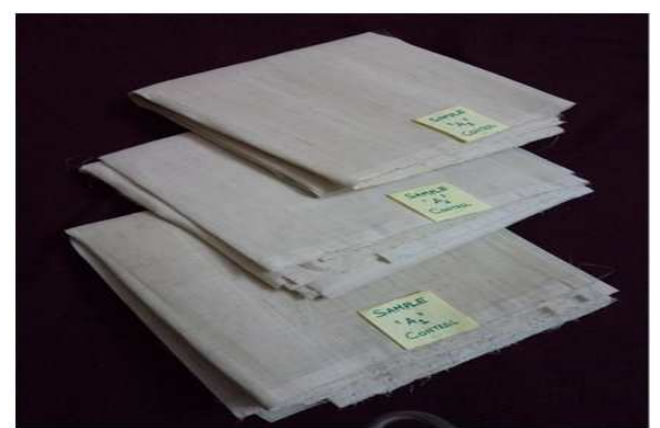

Source: M. Siresha, 2013

Figure 3: Sisal Union Fabric

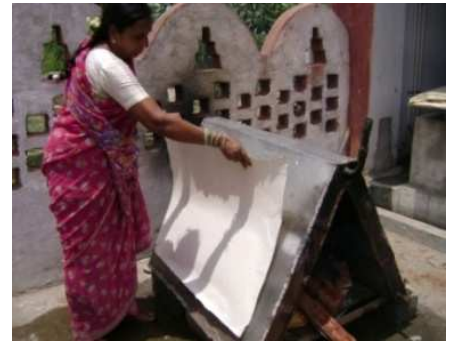

(a) Sisal Handmade Paper

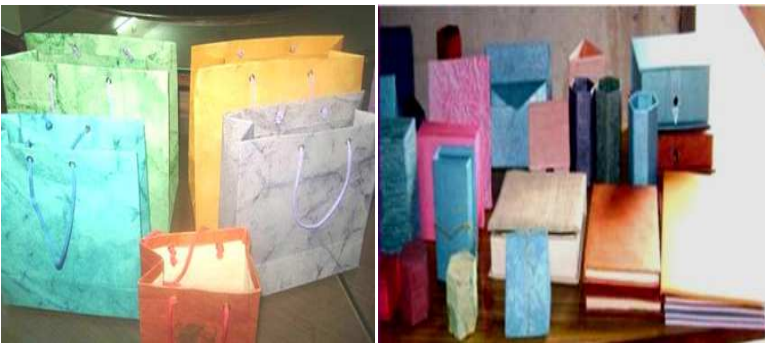

(b) Handmade Paper Carry Bags, Holders, Folders, Gift Envelops, etc

Figure 4: Sisal Handmade Paper and its Crafts 


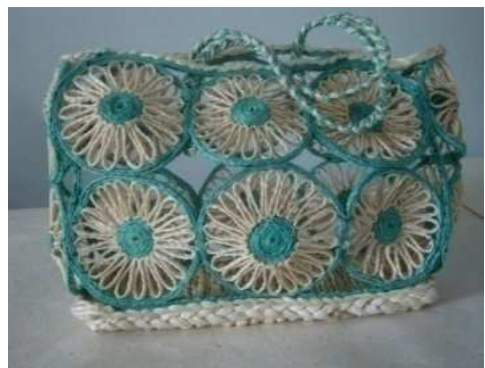

Handbag

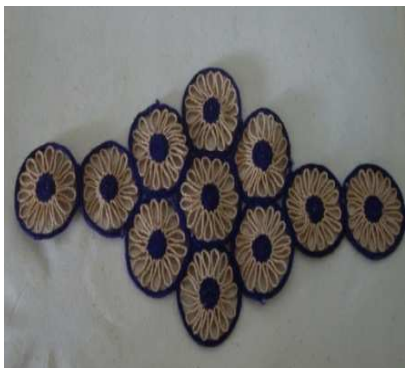

Wall Hanger
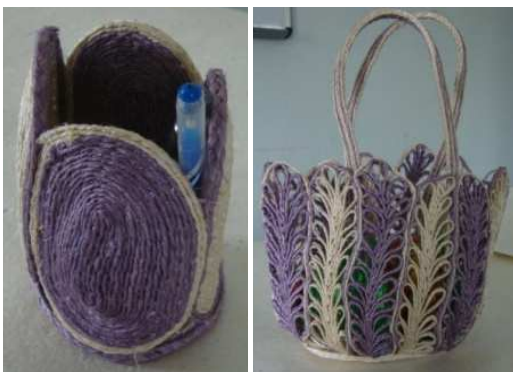

Pen Stand and Hand Bag

Figure 5: Sisal Fiber Handicrafts

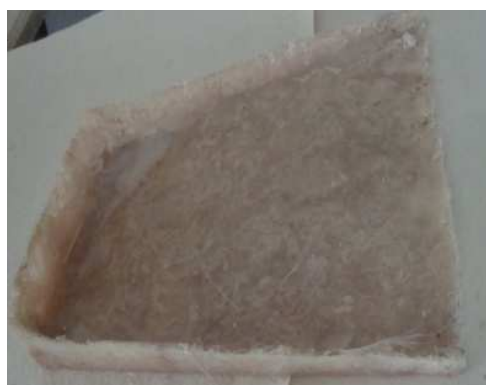

Non Woven Hand

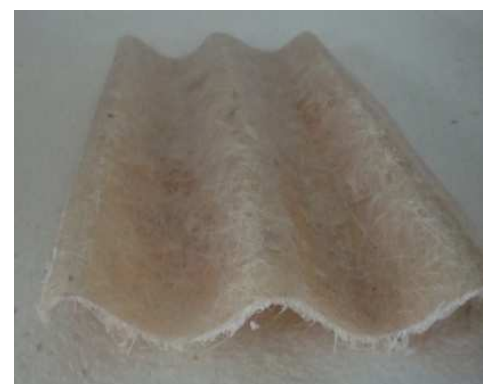

Winnower

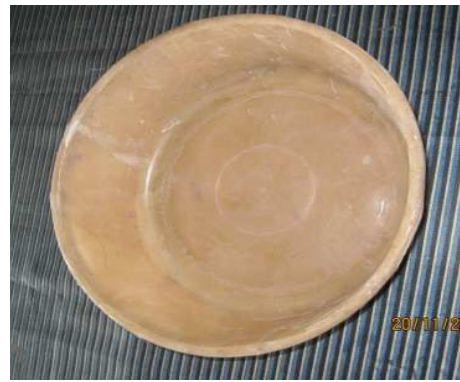

Corrugated Sheet Tub

Figure 6: Composites with Sisal Fiber

\section{CONCLUSIONS}

By using underutilized and bast fibers from agro waste can fetch economic sustainability. As projected in the present paper, these types of fibers can be used to develop many types of diversified products like handicrafts, paper articles, agro mats, composites materials with contemporary models. These fibers can also be used to design and develop special fabrics for their innovative usage. This renewal and impeccable usage of such fibers will lift the hand towards improving the economic status of the needy, includes farm group, self-help groups, etc.

\section{REFERENCES}

1. Corbman Bernard P. 1983. Fiber to Fabric, Edition - 6. Publishers McGraw-Hill International Editions. The Gregg/McGrawHill marketing series.

2. Filho, R. D. T., Barbosa, N. P. and K. Ghavami, Application of sisal and coconut fibres in adobe blocks. In: Vegetable plants and their fibres as building materials: Proceedings of the 2nd international symposium sponsored by the International Union of Testing and Research Laboratories for Materials and Structures (RILEM, September 17- 21(1990), pp.139-149.

3. Lock, G. W. Sisal. 1962. Tangangika sisal growers Association, London: Longmans

4. M. Siresha, 2013. M. Sc. (Textiles and Apparel Designing) Thesis on: Performance characteristics of designed eco- friendly Sisal union fabrics, submitted to Apparel and Textiles Department, College of Home Science.

5. Gopakumar. R et. al., Development and Characterization of Eco-Friendly Sisal Fiber-Natural Rubber Latex Composites. International Journal Of Mechanical And Production Engineering Research And Development (IJMPERD) Volume 7, Issue 4, July-August 2017, pp. 57-64

6. Mattoso, L. H. C., Ferreira, F. C. Curvelo, A. A. S. 1997. Sisal fiber: Morphology and applications in polymer composites. In: LEAO, A. L.; Carvalho, F. X.; Frollini, E Lignocellulosic-plastics composites, Sao Paulo: USP/UNESP.21-51. 
7. Nilsson, L. 1975. Reinforcement of concrete with sisal and other vegetable fibres. Stockholm: Swedish Building Research Summaries. D-14: 68

8. Padma Alapati and Khateeja Sulthana Shaik. 2016. Annual report under All India Coordinated Research Project on Home Science, Clothing and Textiles Component. PJTSAU. Pg: 51-57.

9. P Srinivasakumar, M J Nandan, C Udaya Kiran, K Prahlada Rao. 2013. Sisal and its Potential for Creating Innovative Employment Opportunities and Economic Prospects. Journal of Mechanical and Civil Engineering. Vol. 8(6): 01-08.

10. Weindling, L., 1947. Long vegetable fibres. New York: Columbia University Press.

11. Wilson, P. I. 1971. Sisal. Rome: FAO/United Nations Organization, Hard Fibres Research Series, Vol. II, No. 8 